\title{
KAJIAN TENTANG PERKEMBANGAN E-BUSINESS \\ TERHADAP PRAKTIK BISNIS
}

\author{
Herman; Yakub \\ Jurusan Teknik Informatika, STMIK Dharma Putra, Jln. Otto Iskandar Dinata No. 80 Tangerang \\ herman@dharmaputra.ac.id; y44kub@yahoo.com
}

\begin{abstract}
The simple reason that businesses use internet technology is for increasing and changing their main business processes. Most of companies have already grown from traditional business practices to e-business practices. The growth of internet affects the way of how the company changes their design, process, produce, market, and deliver the product. Product delivering process in digital way through internet is predicted to increase in various business sectors. In order to implement the e-business concept, a company needs at least one of their business partners matching six group type according to the rules and functions.
\end{abstract}

Keywords: e-business, delivering process, digital

\section{ABSTRAK}

Alasan bisnis dalam menggunakan teknologi internet yaitu untuk meningkatkan dan mengubah bentuk proses bisnis utama mereka. Kebanyakan perusahaan sudah berkembang dari praktik bisnis traditional menjadi praktik e-bisnis. Efek perkembangan internet untuk bagaimana perusahaan mengubah desain, proses, produksi, pasar, dan pengiriman produk mereka. Proses pengiriman produk dalam digital melalui internet diprediksikan akan meningkat dalam berbagai sector bisnis. Untuk mengimplementasikan konsep e-bisnis, sebuah perusahaan membutuhkan setidaknya satu rekan bisnis mereka dari enam jenis kelompok yang sesuai dengan peraturan dan fungsi.

Keywords: e-business, proses pengiriman, digital

\section{PENDAHULUAN}

Sering dijumpai dalam berbagai kesempatan para praktisi bisnis maupun teknologi informasi yang keliru mempergunakan istilah e-commerce dan e-business dalam presentasinya. Hal ini sangat wajar karena selain disebabkan oleh banyaknya teori yang berkembang sehubungan dengan kedua fenomena bisnis tersebut, kecepatan kemajuan teknologi informasi semakin memperluas dan mengaburkan arti dari e-commerce maupun e-business. Namun hampir semua praktisi dan ahli bisnis maupun teknologi informasi sepakat pada konsep yang mengatakan bahwa domain e-business jauh lebih luas dibandingkan dengan domain e-commerce. Fenomena e-business tidak dapat disangkal lagi telah menjadi trend yang mewarnai aktifitas bisnis di negara-negara maju maupun berkembang. Konsep baru yang berkembang karena kemajuan teknologi informasi dan berbagai paradigma bisnis baru ini dianggap sebagai kunci sukses perusahaan-perusahaan di era informasi dan di masamasa mendatang.

Teknologi informasi meliputi segala alat maupun metode yang terintegrasi untuk digunakan dalam menjaring atau menangkap data (capture), menyimpan (saving), mengolah (process), mengirim (distribute), atau menyajikan kebutuhan informasi secara elektronik ke dalam berbagai format, yang bermanfaat bagi pemakai (user). Teknologi ini dapat berupa kombinasi perangkat keras dan lunak dari komputer, non komputer maupun prosedur, operator, dan para manajer dalam suatu sistem yang terpadu satu sama lain. Perkembangan teknologi informasi telah mengakibatkan perubahan dalam struktur serta praktik pengelolaan organisasi bisnis di dalam berkompetisi dan melaksanakan kegiatan untuk melayani pelanggan, sehingga dengan laju perkembangan teknologi informasi yang semakin pesat telah mengubah bisnis dan konsep manajemen yang ada, juga berdampak terhadap kebutuhan informasi bagi manajer guna mendukung dalam pemecahan masalah untuk pengambilan keputusan, meraih peluang, dan mancapai tujuan.

Perkembangan teknologi internet saat ini lebih banyak berkembang ke arah user friendly, yang artinya semakin mempermudah pemakai dalam memahami serta menjalankan fungsi internet. Dalam dunia usaha khususnya bidang pemasaran, internet merupakan salah satu media pemasaran yang bersifat global. Informasi bagi suatu perusahaan merupakan bagian yang sangat penting dalam memecahkan masalah untuk mencapai tujuan, meraih peluang dan tindakan pengambilan keputusan yang tepat dan mendasar.

Informasi bagi sebuah perusahaan merupakan bagian yang sangat penting dalam memecahkan masalah untuk mencapai tujuan, meraih peluang dan tindakan pengambilan keputusan yang cepat dan mendasar. Informasi didapatkan dari sistem informasi (information system) yaitu sebuah sistem di dalam organisasi yang mempertemukankebutuhan pengolahan transaksi harian dalam mendukung kegiatan operasional baik yang bersifat manajerial maupun berupa kegiatan strategi yang mampu menyediakan laporan-laporan berupa informasi kegiatan kepada pihak yang berkepentingan.

\section{Tinjauan Pustaka}

\section{E-Business}

E-Business adalah penggunaan teknologi informasi untuk memudahkan proses bisnis, melakukan e-commerce dan menyediakan kerjasama untuk mendukung komunikasi perusahaan. Hampir sama dengan e-commerce, istilah 
e-business mengacu pada penggunaan internet untuk berdagang. Adanya kesamaan terminologi dengan e-mail, e-commerce, karena sama-sama menggunakan internet. Istilah yang lebih umum dibanding e-commerce, tidak hanya pada pembelian dan penjualan, tetapi juga pada pelayanan pelanggan dan bekerja dengan mitra bisnis. Pengertian paling sederhana, e-business adalah penggunaan teknologi internet untuk meningkatkan dan mengubah bentuk proses bisnis utama. Kebanyakan perusahaan sudah mulai banyak berkembang dari praktik bisnis tradisional ke e-business.

Transaksi dapat dilakukan antara berbagai pihak, secara umum jenis transaksi tersebut dilakukan dengan B2B, $\mathrm{B} 2 \mathrm{C}, \mathrm{C} 2 \mathrm{C}, \mathrm{C} 2 \mathrm{~B}$, dan $\mathrm{G} 2 \mathrm{C}$, yang dijelaskan sebagai berikut: (1) business to business (B2B), dalam transaksi B2B baik penjual maupun pembeli adalah organisasi bisnis; (2) business to custumers (B2C), dalam transaksi B2C penjual adalah perusahaan dan pembelinya adalah perorangan; (3) consumers to consumers $(\mathrm{C} 2 \mathrm{C})$, dalam $\mathrm{C} 2 \mathrm{C}$ seseorang menjual produk atau jasa ke orang lain. $\mathrm{C} 2 \mathrm{C}$ dapat juga sebagai customer to customer (pelangan ke pelanggan. Kedua istilah ini dianggap sama, dan keduanya akan menjelaskan orang-orang yang menjual produk dan jasa ke satu sama lain; (4) consumer to business ( $\mathrm{C} 2 \mathrm{~B})$, dalam $\mathrm{C} 2 \mathrm{~B}$ konsumen memberitahukan atas suatu produk atau jasa tertentu, dan para pemasok bersaing untuk menyediakan produk atau jasa tersebut ke konsumen; (5) government to citizen (G2C) dan pihak lain, dalam kondisi ini unit pemerintah menyediakan layanan ke para warganya melalui teknologi Electronic Commerce (EC). Unit-unit pemerintah dapat melakukan bisnis dengan berbagai unit pemerintah lainnya serta dengan berbagai perusahaan Government to Government (G2B) lihat gambar 1, 2, dan 3.

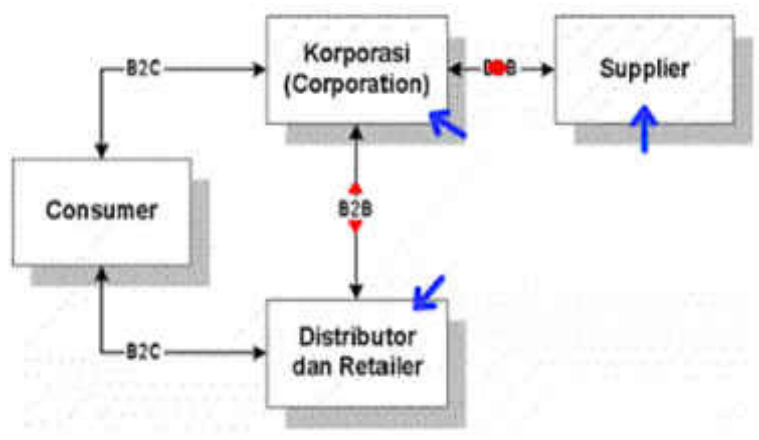

Gambar 1 Model Bisnis B2B

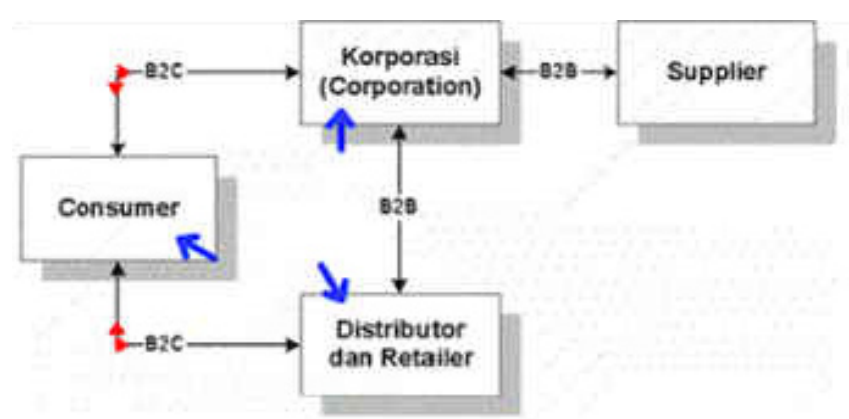

Gambar 2 Model Bisnis B2C

Perkembangan internet akan berdampak pada perubahan dan cara organisasi merancang, memproses, memproduksi, memasarkan, dan menyampaikan produk. Lingkup persaingan yang semakin luas juga menuntut integrasi dan koordinasi antara departemen sistem informasi, pemasaran, layanan pelanggan, dan departemen-departemen lainnya dalam organisasi, beraneka ragam peluang pemanfaatan internet yang dapat dieksploitasi meliputi sumber baru untuk informasi pasar, individualized/customized marketing, cara baru menjalin relasi online dengan pelanggan dan membangun citra merek (interactive marketing), peluang baru bagi distribusi produk dan komunikasi pemasaran.

Untuk menjalankan berbagai aplikasi di atas perusahaan membutuhkaninformasi, infrastruktur, danlayananpendukung yang tepat. Area pendukung tersebut adalah orang, kebijakan publik, pemasaran, layanan pendukung, dan kemitraan bisnis, adalah (1) orang, yaitu para penjual, pembeli, perantara, ahli sistem informasi, dan karyawan, serta peserta lainnya; (2) kebijakan publik, yaitu berbagai isu hukum dan kebijakan serta peraturan lainnya; (3) pemasaran dan periklanan, yaitu dukungan pemasaran dan periklanan seperti bisnis lainnya; (4) layanan pendukung, berbagai layanan, dari pembayaran hingga pengiriman pesanan serta pembuatan isi; (5) kemitraan bisnis, usaha bersama, pasar elektronik.

Sebagai model pemasaran kontemporer, e-business membawa dampak positif bagi tiga pihak; produsen, perantara, dan pelanggan. Produsen dapat menjangkau lebih banyak konsumen, mengumpulkan informasi yang lebih akurat mengenai perilaku konsumen, menentukan pasar sasaran secara lebih efektif, dan melayani konsumen secara lebih baik dan memuaskan. Perantara dapat memperoleh komisi dan fee transaksi atas jasa-jasa bernilai tambah, seperti pengumpulan dan analisis informasi, pemrosesan pesanan dan pembayaran terintegrasi dalam sistem teknologi informasi penjual dan pembeli, serta jasa konsultasi. Sedangkan pelanggan dapat membandingkan dan memilih produk dan harga secara lebih mudah dan akurat, sehingga bargaining power konsumen semakin menguat.

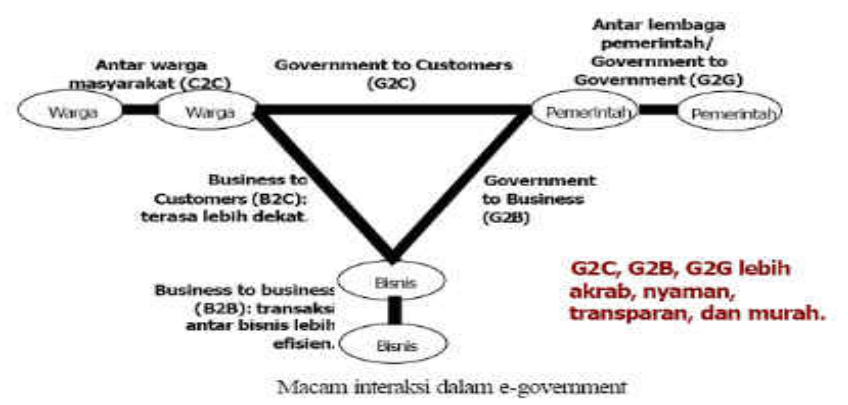

Gambar 3 Interaksi Antar Pelaku Dalam E-Government

\section{Internet}

Internet (the net) adalah jejaring yang menghubungkan sekitar satu juta komputer organisasi internasional (Turban, Rainer \& Potter, 2005). Jejaring komputer organisasional internal ini mencakup sistem komputer universitas, perusahaan, rumah sakit, dan sebagainya. Sistem komputer yang berpatisipasi ini disebut node, yang mencakup PC, LAN (Local Area Network), basis data, dan mainframe. Di Internet, node dapat mencakup beberapa jaringan dari satu organisasi yang mungkin dihubungkan oleh WAN (Wide Area Network). Sebagai satu atau beberapa jejaring, internet memungkinkan orang untuk mengakses data di organisasi lainnya dan untuk berkomunikasi, bekerjasama, dan bertukar informasi di hampir seluruh dunia. Jadi internet telah menjadi keharusan dalam melaksanakan bisnis modern.

Internet berasal dari kata interconnection networking yang mempunyai arti hubungan komputer dengan berbagai tipe yang membentuk sistem jejaring yang mencakup seluruh dunia (jejaring komputer global) dengan melalui jalur telekomunikasi seperti telepon, radio link, satelit dan lainnya. Dalam mengatur integrasi dan komunikasi jejaring komputer ini digunakan protokol yaitu TCP/IP. TCP (Transmission Control Protocol) bertugas memastikan bahwa semua hubungan bekerja dengan benar, sedangkan IP (Internet Protocol) yang mentransmisikan data dari satu komputer ke komputer lain. TPC/IP secara umum berfungsi memilih rute terbaik transmisi data, memilih rute alternatif jika suatu rute tidak dapat digunakan, mengatur dan mengirimkan paket- 
paket pengiriman data. Untuk dapat ikut serta menggunakan fasilitas Internet, biasanya harus berlangganan ke ISP (Internet Service Provider).

\section{PEMBAHASAN}

\section{Perkembangan Teknologi Informasi dan E-Business}

Teknologi informasi meliputi segala alat maupun metode yang terintegrasi untuk digunakan dalam menjaring atau menangkap data (capture), menyimpan (saving), mengolah (process), mengirim (distribute), atau menyajikan kebutuhan informasi secara elektronik ke dalam berbagai format, yang bermanfaat bagi pengguna (user). Teknologi ini dapat berupa kombinasi perangkat keras dan lunak dari komputer, non komputer maupun prosedur, operator, dan para manajer dalam suatu sistem yang terpadu satu sama lain. Perkembangan teknologi informasi telah mengakibatkan perubahan dalam struktur serta praktik pengelolaan organisasi bisnis di dalam berkompetisi dan melaksanakan kegiatan untuk melayani pelanggan, sehingga dengan laju perkembangan teknologi informasi yang semakin pesat telah mengubah bisnis dan konsep manajemen yang ada, juga berdampak terhadap kebutuhan informasi bagi manajer guna mendukung dalam pemecahan masalah untuk pengambilan keputusan, meraih peluang, dan mancapai tujuan. Sebagaimana diketahui bahwa internet merupakan salah satu infrastruktur utama dalam e-business. Istilah e-business berkaitan erat dengan e-commerce. Bagi sebagian kalangan istilah e-commerce diartikan secara sempit sebagai transaksi jual beli produk, jasa dan informasi antar mitra bisnis lewat jejaring komputer, termasuk internet. Sedangkan e-business mengacu pada lingkup yang lebih luas dan mencakup layanan pelanggan, kolaborasi dengan mitra bisnis, dan transaksi elektronik internal dalam sebuah organisasi.

\section{Peluang dan Tantangan E-Business}

Perkembanganinternetakanberdampakpadaperubahan dan cara organisasi merancang, memproses, memproduksi, memasarkan, dan menyampaikan produk. Lingkup persaingan yang semakin luas juga menuntut integrasi dan koordinasi antara departemen sistem informasi, pemasaran, layanan pelanggan, dan departemen-departemen lainnya dalam organisasi, beraneka ragam peluang pemanfaatan internet yang dapat dieksploitasi meliputi sumber baru untuk informasi pasar, individualized/customized marketing, cara baru menjalin relasi online dengan pelanggan dan membangun citra merek (interactive marketing), dan peluang baru bagi distribusi produk dan komunikasi pemasaran.

Proses penyampaian (delivery) produk secara digital via internet diperkirakan bakal semakin marak dalam berbagai sektor bisnis, terutama untuk program perangkat lunak, surat kabar, musik, tiket pesawat, sekuritas, jasa konsultasi, hiburan, perbankan, asuransi, pendidikan, dan perawatan kesehatan. Sekalipun ada banyak sekali daya pikat e-business (terutama yang berbasis internet), masih ada sejumlah tantangan atau keterbatasan yang harus diatasi. Dalam lingkup yang lebih luas, perkembangan e-business dalam kontek ekonomi baru (new economy) atau webeconomics masih menghadapi sejumlah tantangan besar, diantaranya: (1) peningkatan ketersediaan dan kecepatan akses internet secara luas dan sejauh ini tingkat penetrasi internet masih rendah; (2) pembenahan infrastruktur (seperti perangkat lunak dan perangkat keras), serta regulasi (menyangkut tarif telepon, jasa, ISP, dan Undang-undang tentang e-Commerce); (3) isu privasi dan keamanan dalam transaksi via internet terutama masalah kartu kredit "illegal". Hal ini mempengaruhi rendahnya tingkat kepercayaan (trust) masyarakat, yang pada gilirannya menyebabkan masih rendahnya volume transaki online; (4) dalam banyak kategori produk, masyarakat lebih menyukai model bisnis konvensional, contoh, masih banyak orang yang lebih suka membolak-balik majalah atau buku tertentu sebelum memutuskan untuk membeli; (5) biaya dan justifikasi, misalnya; menyangkut keputusan mengembangkan e-business sendiri versus outsourcing, kriteria memilih pemasok perangkat lunak dan infrastruktur, sulitnya mengkuantifikasi manfaat intangible dari sistem e-business (misalnya: layanan pelanggan yang lebih baik dan nilai periklanan); (6) kecepatan dan kemudahan jasa-jasa penunjang, seperti; logistik dan distribusi fisik, yang sangat diperlukan dalam mendukung efektifitas dan efisiensi layanan e-business.

Sebagai model pemasaran kontemporer, e-business membawa dampak positif bagi tiga pihak; produsen, perantara, dan pelanggan. Produsen dapat menjangkau lebih banyak konsumen, mengumpulkan informasi yang lebih akurat mengenai perilaku konsumen, menentukan pasar sasaran secara lebih efektif, dan melayani konsumen secara lebih baik dan memuaskan. Perantara dapat memperoleh komisi dan fee transaksi atas jasa-jasa bernilai tambah, seperti pengumpulan dan analisis informasi, pemrosesan pesanan dan pembayaran terintegrasi dalam sistem teknologi informasi penjual dan pembeli, serta jasa konsultasi. Sedangkan pelangan dapat membandingkan dan memilih produk dan harga secara lebih mudah dan akurat, sehingga bargaining power konsumen semakin menguat.

\section{Mitra Kerjasama E-Business}

Dalam mengimplementasikan konsep e-business, suatu perusahaan pasti membutuhkan mitra kerja. Dilihat dari fungsi dan peranannya bagi perusahaan, berbagai mitra kerja ini dapat dikelompokkan menjadi enam jenis, yaitu; strategic service partners (SSP), non strategic service partners (NSP), commodity suppliers (CS), value added suppliers $(V A S)$, network operations partners (NOP), dan application service provider (ASP). Mitra kerja sama e-business sebuah perusahaan dapat dilihat pada gambar sebagai berikut.

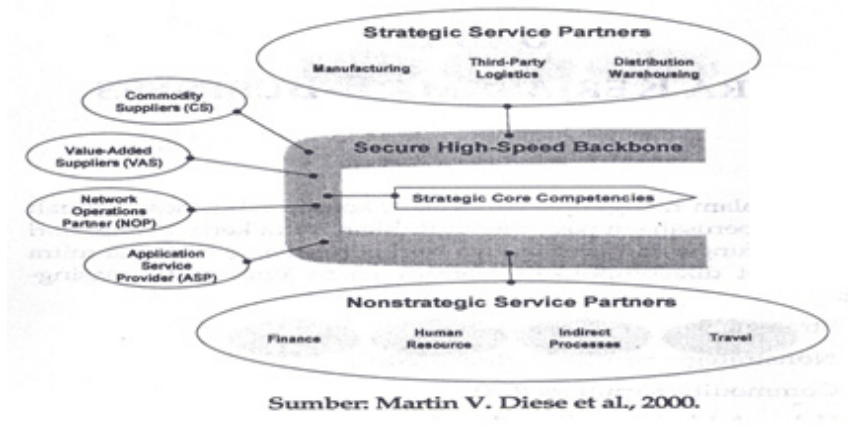

Gambar 4. Mitra Kerjasama E-Business Sumber: Indrajit (2002)

Strategic service partners, perusahaan dikategorikan sebagai mitra kategori SSP jika yang bersangkutan membantu perusahaan yang berhubungan dengan pelaksanaan proses intinya (core business process). Contohnya, perusahaan publikasi buku, editing dan layout merupakan dua buah jenis rangkaian proses inti. Karena semakin banyak permintaan akan buku yang harus diedit maupun dilayout, sementara kapasitas SDM yang ada saat ini perusahaan tidak dapat memenuhi permintaaan, maka yang bersangkutan melalukan kerjasama outsourcing kesatu atau lebih perusahaan SSP.

Non strategic service partners, cara kerja NSP lebih sama dengan SSP, hanya saja yang dilakukan oleh mitra kerja ini adalah bukan melakukan proses inti, namun lebih menfokuskan diri pada aktifitas-aktifitas pendukung (supporting process). Contoh yang sekarang sedang menjadi 
trend adalah outsourcing proses-proses back office perusahaanperusahaan di suatu negara ke perusahaan-perusahaan negara lain.

Commodity suppliers, di antara berbagai bahan (material) atau sumber daya yang dibutuhkan perusahaan untuk menghasilkan produk atau jasa yang ditawarkan, banyak terdapat bahan-bahan yang berupa komoditas. Hal ini perlu sekali dibedakan dengan jenis-jenis barang lainnya karena di internet, barang-barang komoditas dapat dibeli melalui mekanisme lelang maupun lelang terbalik (reverse auction). Intinya adalah dengan melakukan kerja sama dengan perusahaan yang menangani perdagangan CS, maka perusahaan akan dapat bahan (material) yang dibutuhkan dengan harga semurah mungkin.

Value added suppliers, yang termasuk dengan VAS adalah mitra yang produk atau jasanya dipergunakan oleh perusahaan untuk meningkatkan nilai produk atau jasa yang ditawarkan kepada pelanggan. Contohnya adalah perusahaan pengemas (pemaket) produk yang dibeli oleh pelanggan untuk diberikan sebagai hadiah (kado) bagi orang lain yang sedang berulang tahun.

Network operations partner, konsep e-business adalah perkawinan antara manajemen bisnis modern dengan teknologi informasi, artinya tanpa adanya jaringan atau infrastruktur teknologi informasi (komputer dan telekomunikasi) yang handal, akan sulit bagi perusahaan untuk melakukan operasinya. NOP adalah mitra perusahaan yang menyediakan produk teknologinya mulai dari jejaring infrastruktur, konektivitas, telekomunikasi, komputerisasi, dan perangkat keras lainnya untuk dipergunakan (disewa) perusahaan sebagai prasyarat fasilitas minimum untuk mengimplementasikan konsep e-business.

Application service provider, setelah memiliki mitra kerja yang mengurusi perangkat keras (hardware) dan perangkat SDM di masing-masing proses (brainware), tibalah saatnya perusahaan perangkat mencari mitra ASP yang mengkhususkan diri pada penyediaan perangkat lunak aplikasi implementasi konsep e-business (software). Aplikasi yang dimaksud disini sifatnya beragam, mulai dari sistem operasi, basis data, programming language, website, sampai dengan aplikasi bisnis semacam decision support systems dan intelligenece system yang sifatnya membantu perusahaan dalam menjalankan konsep e-business.

\section{Dampak E-Business terhadap Praktik Bisnis}

E-Business merupakan bidang kajian yang relatifmasih baru dan akan terus berkembang. Kendati demikian, e-business berdampak besar pula pada praktik bisnis. Setidaknya dalam tiga kategori ini dapat menyempurnakan direct marketing, mentransformasi organisasi, dan mendefinisikan organisasi.

Dalam kategori pertama, e-business berdampak pada akselarasi pertumbuhan direct marketing yang secara tradisional berbasis mail order (katalog) dan telemarketing. Kemunculan e-business memberikan beberapa dampak positif bagi aktifitas pemasaran, diantaranya: (1) memudahkan promosi produk dan jasa secara interaktif dan real time melalui saluran komunikasi langsung via internet; (2) menciptakan saluran distribusi baru yang dapat menjangkau lebih banyak pelanggan di hampir semua belahan dunia; (3) memberikan penghematan siginifikan dalam hal biaya pengiriman informasi dan produk terdigitalisasi (contohnya, perangkat lunak dan musik); (4) menekan waktu siklus dan tugas-tugas administratif (terutama untuk pemasaran internasional) mulai dari pesanan hingga pengiriman produk; (5) layanan pelanggan yang lebih responsif dan memuaskan karena pelanggan dapat mendapatkan informasi lebih rinci dan respon cepat secara online; (6) memfasilitasi mass customization yang telah diterapkan pada sejumlah produk, seperti komputer, komestik, mobil, rumah, permata, bingkisan hadiah (gifts), kartu ucapan, bunga, asuransi, jasa perjalanan wisata, buku, CD, mebel, arloji, t-shirts, dan berbagai macam produk lainnya; (7) memudahkan aplikasi one to one atau direct advertising yang lebih efektif dibandingkan mass advertising; (8) menghemat biaya dan waktu dalam menangani pesanan, karena sistem pemesanan elektronis memungkinkan pemrosesan yang lebih cepat dan akurat; (9) menghadirkan pasar maya atau virtual (marketspace) sebagai komplemen pasar tradisional (marketplace).

Dalam hal transformasi organisasi, e-business mengubah karaktersitik pekerjaan, karir, dan kompensasi. E-business menuntut kompetisi, komitmen, kreatifitas, dan fleksibilitas karyawan dalam beradaptasi dengan setiap perubahan lingkungan. Konsekuensinya, organisasi dituntut untuk memiliki struktur yang ramping, bercirikan pemberdayaan dan desentralisasi wewenang, beranggotakan knowledge based workers, mampu beradaptasi secara cepat dengan teknologi baru dan perubahan lingkungan (learning organization), mampu dan berani bereksperimen dengan produk, jasa, maupun proses baru, dan mampu mengelola perubahan secara strategik.

Sedangkan dalam hal redefinisi organisasi, e-business memunculkan model bisnis baru yang berbasis jasa online di marketspace. Hal ini dapat berdampak pada redefinisi misi organisasi dan cara organisasi menjalankan bisnisnya. Perubahan ini antara lain meliputi peralihan dari sistem produksi masal menjadi pemanufakturan Just In Time (JIT) yang lebih customized, pengintegrasian berbagai sistem fungsional (seperti; produksi, keuangan, pemasaran, dan sumber daya manusia), baik secara internal maupun dengan mitra bisnis dan pelanggan, penerapan sistem pembayaran baru, seperti electronic cash, penguasaan sistem informasi dan teknologi mutakhir, dan penerapan sistem belajar dan pelatihan online.

\section{SIMPULAN}

Perkembangan teknologi informasi telah mengakibatkan perubahan dalam struktur serta praktik pengelolaan organisasi bisnis di dalam berkompetisi. E-business mengacu pada lingkup yang lebih luas yang mencakup layanan pelanggan, kolaborasi dengan mitra bisnis, dan transaksi elektronik. Sebagai model pemasaran kontemporer, e-business membawa dampak positif bagi produsen, perantara, dan pelanggan.

Implementasi e-business pada suatu perusahaan membutuhkan mitra kerja menurut fungsi dan peranannya di dalam perusahaan. Pertukaran barang dan jasa melalui internet (e-business) dapat membantu perusahaan menurunkan biaya pengeluaran operasional. E-business menuntut kompetisi, komitmen, kreatifitas, dan fleksibilitas karyawan dalam beradaptasi dengan setiap perubahan lingkungan. Konsekuensinya, organisasi dituntut memiliki struktur yang ramping, bercirikan pemberdayaan dan desentralisasi wewenang.

\section{DAFTAR PUSTAKA}

Indrajit, R. E. (2002). Konsep dan Aplikasi E-Business. Yogyakarta: Andi.

Turban, E., Rainer, R. K., \& Potter, R. E.. (2005). Introduction to Information Technology (Pengantar Teknologi Informasi). Jakarta: Salemba Infotex.

Sawyer, W. (2007). Using Information Technology, Pengenalan Praktis Dunia Komputer dan Komunikasi, Yogyakarta: Andi. 